\title{
Mannréttindastefna Reykjavíkurborgar: Áskoranir, togstreita og tækifæri
}

\author{
Porgerður H. porvaldsdóttir, sagn- og kynjafræđingur, Reykja- \\ víkurAkademíunni ${ }^{1}$
}

Guðbjörg Lilja Hjartardóttir, stjórnmálafræðingur, ReykjavíkurAkademíunni²

\section{Útdráttur}

Reykjavíkurborg tók ákveðið frumkvæði í jafnréttis- og mannréttindamálum á Íslandi pegar mannréttindastefna borgarinnar var sampykkt árið 2006. Stefnan ber sterkan svip af regluverki Evrópusambandsins par sem áhersla er lögð á jafnrétti allra hópa og bann við mismunun. Innleiðing og framkvæmd mannréttindastefnunnar hefur reynst vandasamt ferli, ekki síst par sem löggjöf um bann við mismunun hér á landi er ábótavant, nema á sviði kynjajafnréttis, og hefur pað haft bein áhrif á stöðu málaflokksins. Spurningakönnun sem lögð var fyrir stjórnendur hjá Reykjavíkurborg um mannréttindastefnuna, fordóma og stöðu jaðarsettra hópa leiddi í ljós að í grunninn virðist mannréttindastefna Reykjavíkurborgar vera gott verkfæri. Stefnan er ágætlega pekkt meðal stjórnenda og peir nýta hana sem tæki til breytinga, sér í lagi pegar kemur að mannaráðningum og starfsmannahaldi, en minna við úrhlutun fjármagns. Prátt fyrir ásetning um að sinna jafnrétti allra og vinna gegn margpættri mismunun virðast sumir jaðarsettir hópar berskjaldaðri fyrir mismunun og jaðarsetningu en aðrir, sérstaklega innflytjendur, fatlað fólk og langveikt fólk.

Efnisorð: Mannréttindastefna Reykjavíkurborgar; margpætt mismunun; samtvinnun mismununarbreyta; mannréttindaborg. 


\title{
The city of Reykjavík's human rights policy: Challenges, dilemmas and opportunities
}

\begin{abstract}
The City of Reykjavík took the lead in promoting equality and human rights in Iceland when the City Council adopted the first human rights policy in 2006. The policy is based on international human rights law and principles of equality and non-discrimination. A questionnaire for the city's managers and administrators, enquiring about their experience of the human rights policy, prejudice and the status of marginalized groups, demonstrated various challenges in implementing and promoting the policy. This is due, not the least, to the fact that the national legislation on ban on discrimination is limited to gender equality, thus halting further development in the field of human rights. The human rights policy is fairly well known by the city's managers and administrators. They apply the policy in their different and demanding jobs especially in human resource management but to a limited extent in finance management. The policy has thus proven to be a valuable instrument to bring about changes. The City of Reykjavik aims to achieve equality for all and to work against multiple discrimination. However, some of the marginalized groups seem more vulnerable to discrimination and marginalization than other groups, notably immigrants, people with disabilities and people with long-term health issues.
\end{abstract}

Keywords: Reykjavik's human rights policy; multiple discrimination; institutionalizing intersectionality; human rights city.

\section{Inngangur}

Reykjavíkurborg tók ákveðið frumkvæði í jafnréttis- og mannréttindamálum á Íslandi pegar mannréttindastefna Reykjavíkurborgar var sampykkt einróma í borgarstjórn pann 16. maí 2006. Með pví var jafnréttisstefnu borgarinnar, sem tók á kynjajafnrétti eingöngu, skipt út fyrir víðtæka mannréttindastefnu par sem tiltekið var að allar manneskjur skyldu njóta mannréttinda ,án tillits til uppruna, pjóðernis, litarháttar, trúarbragða, stjórnmálaskoðana, kynferðis, kynhneigðar, aldurs, efnahags, ætternis, fötlunar, heilsufars eða annarrar stöðu“ (Mannréttindastefna Reykjavíkurborgar 16. maí 2006). Lítillega endurskoðuð útgáfa stefnunnar var síðan sampykkt í borgarstjórn 7. maí 2013 og pá var hnykkt á pví að með mannréttindastefnunni sé „unnið gegn margpættri mismunun.“ I kjölfar borgarstjórnarkosninga 2014 var enn ráðist í endurskoðun stefnunnar og rúmum tveimur árum seinna, 18. október 2016, var endurskoðuð mannréttindastefna sampykkt í borgarstjórn. Stefnumótun borgarinnar á sviði mannréttinda, fjölmenningar og kynjajafnréttis rímar vel við löggjöf Evrópusambandsins um bann við mismunun. Slík lög hafa hins vegar ekki verið innleidd á landsvísu, og pví er gap eða tómarúm á milli Evrópusviðsins, landssviðsins og höfuðborgarinnar.

Í greininni verður sjónum beint að mannréttindum í nærumhverfinu. Í pví augnamiði 
verður reynslan af mannréttindastefnu Reykjavíkurborgar skoðuð, en hún byggir á meginreglum alpjóðlegrar mannréttindalöggjafar, jafnræðisreglu stjórnarskrárinnar og lögum um kynjajafnrétti. Útgangspunkturinn er pekkt ummæli Eleanor Roosevelt (1958), en hún stýrði vinnunni við gerð Mannréttindayfirlýsingar Sameinuðu pjóðanna frá 1948. Hún ræddi mikilvægi pess að „færa mannréttindin heim“, pað er, að koma meginreglum alpjóðamannréttindalaga, sem ganga út á jafnrétti og bann við mismunun, inn í okkar daglega líf. Mannréttindahugtakið er margslungið og flókið og pað er rík tilhneiging til pess að tengja pað við „langtíburtistan“ í stað pess að heimfæra pað upp á nærsamfélagið og pólitík hversdagsins, en pað er eitt af markmiðum pessarar greinar. Баð felur ekki eingöngu í sér stefnumótun hins opinbera heldur krefst pað einnig breytinga á hugarfari almennings og að mannréttindi séu á dagskrá í almennu stjórnmálastarfi. Pví verður spurt hvort og pá hvernig veik staða mannréttindamála á vettvangi innanlandsstjórnmála hafi hindrað próun staðbundinna mannréttinda hjá Reykjavíkurborg.

Dó að mannréttindastefna Reykjavíkurborgar hafi verið í gildi í tíu ár hafa engar rannsóknir verið gerðar á pví hvernig til hefur tekist við innleiðingu, framkvæmd og kynningu stefnunnar. Markmið peirrar rannsóknar sem hér er kynnt er að fylla upp í pað pekkingargat. Fyrst munum við pó skoða regluverk Evrópusambandsins um jafnrétti allra og margpætta mismunun - og staðsetja Ísland í málaflokknum, út frá femínískum kenningum um stofnanavæðingu samtvinnunar (e. institutionalizing intersectionality) og alpjóðlegum hugmyndum um mannréttindaborgir. Pví næst verður sjónum beint að Reykjavíkurborg. Fyrst verða saga jafnréttisstarfs hjá borginni og tilurð mannréttindastefnunnar lauslega rakin. Pá verður fjallað um stjórnsýslu borgarinnar í mannréttindamálum og pau verkfæri sem borgin hefur byggt upp til pess að framfylgja stefnunni. Nýnæmi rannsóknarinnar er síðan ítarleg umfjöllun um spurningakönnun sem lögð var fyrir stjórnendur hjá Reykjavíkurborg snemma árs 2014, par sem spurt var um mannréttindastefnu Reykjavíkurborgar, fordóma og stöðu jaðarsettra hópa. Samhliða peirri umræðu verður fjallað um helstu nýjungar og áskoranir sem fram hafa komið við endurskoðun stefnunnar. Í pví sambandi verður sérstaklega rýnt í tvenn drög að nýrri mannréttindastefnu frá árunum 2015 og 2016, og loks í lokaniðurstöðuna, mannréttindastefnu Reykjavíkurborgar sem sampykkt var í borgarstjórn 18. október 2016.

\section{Evrópusambandið, Ísland og margbætt mismunun}

Раð sem einkennt hefur jafnréttisorðræðu og jafnréttisstarf í Evrópu á 21. öldinni eru áherslur á margbreytileika (e. diversity), jafnrétti allra og margpætta mismunun (e. multiple discrimination). Í stað pess að horfa á jafnrétti kynjanna í einangrun, en slíkar áherslur voru t.d. einkennandi á Norðurlöndunum (Kantola 2014; Borchorst et al. 2012), eða halda úti tveggja turna kerfi eins og gert var í Bretlandi par sem einblínt var á kynjajafnrétti annars vegar og kynpátt og réttindi pjóðernisminnihluta hins vegar (Hermanin \& Squires 2012), hefur jafnréttisstarf nú verið útvíkkað til pess að ná utan um jafnrétti ýmissa minnihlutahópa, eða ,jafnrétti allra“. Sérstök áhersla hefur verið lögð á pað sem kallast margpætt mismunun. Evrópusambandið hefur sett upp öflugt regluverk sem snýr að vernd gegn mismunun en pað byggir á mannréttindalöggjöf Sameinuðu pjóðanna 
og Evrópuráđsins. Par ruddi brautina 13. grein Amsterdamsáttmálans frá 1997 (sem 2009 varð 19. grein Lissabonsáttmálans), en par eru tiltekin sex atriði sem ekki mega vera forsendur mismununar, p.e. kyn, kynpáttur eða etnískur uppruni, trú eða trúleysi, fötlun, aldur og kynhneigð. Á peim grunni byggja tvær Evróputilskipanir frá árinu 2000 sem gegnt hafa lykilhlutverki við mótun og uppbyggingu jafnréttisstarfs í Evrópu frá aldamótum. Рað er annars vegar tilskipun 2000/43/EB um bann við mismunun á öllum sviðum samfélagsins á grundvelli kynpáttar eða etnis, en pað er sú mismununartilskipun sem veitir víðtækasta vernd, og hins vegar tilskipun 2000/78/EB um jafna meðferð á vinnumarkaði og í atvinnulífi par sem horft er til trúarbragða eða lífsskoðunar, fötlunar, skertrar starfsgetu, aldurs og kynhneigðar. Auk pess eru nokkrar tilskipanir sem snúa að kynjajafnrétti sem ekki verða útlistaðar hér, en pær falla allar undir EES-samninginn og hafa pví verið innleiddar í gildandi íslensk jafnréttislög. Kynpáttatilskipunin og tilskipunin um vernd á vinnumarkaði falla hins vegar utan EES-samningsins og par af leiðir að Íslandi ber ekki lagaleg skylda til að innleiða pær, og nú, sextán árum síðar, hefur pað ekki enn verið gert. Fyrir vikið er sú réttarvernd sem íslensk löggjöf veitir gegn mismunun sem ekki er bundin við kyn götótt og brotakennd (Oddný Mjöll Arnardóttir 2009; Guðrún Dögg Guðmundsdóttir 2011). Efni mismununatilskipana hefur pó lengi verið á dagskrá hérlendis. Starfshópur um málið var fyrst skipaður af félagsmálaráðherra árið 2006 og hann skilaði skýrslu árið 2008 (Skýrsla starfshóps um tilskipanir Evrópusambandsins um bann við mismunun 2008). Síðan hefur málið verið í vinnslu innan velferðarráðuneytisins og nú liggja fyrir tvenn frumvarpsdrög sem byggja á ofangreindum Evróputilskipunum og eru pau bæði dagsett 17. febrúar 2014. Раð eru, frumvarp til laga um jafna meðferð á vinnumarkaði og frumvarp til laga um jafna meðferð óháð kynpætti eða pjóðernisuppruna. Pegar pinginu var slitið í október 2016, í aðdraganda alpingiskosninga, höfðu frumvörpin ekki enn verið lögð fram. Í norrænu og evrópsku samhengi reka Íslendingar pví lestina pegar kemur að útvíkkun jafnréttisstarfs.

\section{Hugmyndafræðilegur grunnur}

Eitt af markmiðum rannsóknarinnar er að greina að hvaða marki Reykjavíkurborg hefur tekist að innleiða hugmyndafræði samtvinnunar sem aðferðafræði í jafnréttis- og mannréttindastarfi. Kenningar um samtvinnun skoða hvernig félags- og menningarbundin valdamismunun sem verður til í kringum breytur eins og kyn, pjóðerni, kynpátt, kynhneigð, aldur, stétt, fötlun, trúarbrögð o.s.frv. skarast og móta hver aðra. Á peim byggja vaxandi rannsóknaráherslur sem skoða „stofnanavæðingu samtvinnunar“ (Sjá t.d. Kantola 2010, 2014; Krizsan, Skjeig \& Squires 2012; Kantola \& Nousiainen 2009; Lombardo \& Verloo 2009; Porgerður Porvaldsdóttir 2012, 2014), pað er hvernig útvíkkun jafnréttisstarfs verður best sinnt og hvernig taka beri á neikvæðum samlegðaráhrifum slíkrar skörunar, sem kölluð hafa verið margpætt mismunun.

pá verður mannréttindastefna Reykjavíkurborgar skoðuð með hliðsjón af niðurstöðum QUING-hópsins, en hann var stór evrópskur rannsóknarhópur sem skoðaði jafnréttisstarf og jafnréttispólitík í 27 Evrópusambandslöndum á árunum 2006-2011. QUING-hópurinn kynnti til sögunnar hugtakið Gender + Equality Policies, sem pýða 
mætti sem kynjajafnrétti+. Niðurstaða hópsins var að alvöru jafnréttisstarf pyrfti alltaf að horfa á heildarmyndina par sem allar breyturnar eru undir og tekist er á við pær samhliða og sem órjúfanlegan hluta af kynjajafnrétti (Sjá QUING - Quality in Gender+ Equality Policies, (www.quing.eu). Mieke Verloo, verkefnisstjóri QUING verkefnisins, hrakti efasemdir um að kynjajafnrétti+ pýddi að kynjabreytan fengi minna vægi. Hún minnti á að ef plúsarnir, sem standa fyrir annars konar mismunun, væru undanskildir pannig að innflytjendakonur, fatlaðar konur, gamlar konur, fátækar konur og hinsegin konur (og hér getum við í öllum tilfellum talað um karla líka) væru sífellt teknar út fyrir og settar í sviga, er hætt við að jafnréttisstarf pjónaði fyrst og fremst fólki í forréttindastöðu en ekki peim hópum sem eru jaðarsettir í samfélaginu (Verloo 2011).

рá verður hugað að grundvallarspurningum sem snúast um jafnrétti hverra beri að sinna andspænis pví hverskonar jafnréttisstarf skuli ástundað (Dorgerður Porvaldsdóttir 2014, 293-296). Par verður sérstaklega horft til gagnrýni finnska kynja- og stjórnmálafræðingsins Johanna Kantola (2014) en hún heldur pví fram að með útvíkkun jafnréttisstarfs, frá kynjajafnrétti yfir í margpætta mismunun, hafi fylgt ákveðnar áherslubreytingar í jafnréttisstarfi. Par sem kynjajafnrétti var í forgrunni, eins og á Norðurlöndunum, ríkti sá skilningur að (kynja)misrétti væri samfélagslegur vandi sem stjórnvöldum, peim sem vinna að stefnumótun, atvinnurekendum og veitendum pjónustu, bæri að takast á við. Meðölin sem beitt var voru prípætta módelið, bann við mismunun, sértækar aðgerðir og kynjasampætting. Kantola heldur pví fram að í hinu samtvinnaða evrópska módeli, par sem margpætt mismunun er sett á oddinn, hafi jákvæðar, fyrirbyggjandi aðferðir eins og sértækar aðgerðir og kynjasampætting vikið fyrir einföldu banni við mismunun (e. antidiscrimination framwork). Đar eru pað sannarlega stjórnvöld sem setja lagarammann en pað er á ábyrgð peirra einstaklinga sem brotið er á að sækja rétt sinn, sanna að mismunun hafi átt sér stað og leggja pá fram kæru (Kantola 2014, 9). Skoðað verður hvort og pá hvernig pessar áherslubreytingar hafi fylgt með í kaupunum pegar Reykjavíkurborg útvíkkaði sína (kynja)jafnréttisstefnu og skipti henni út fyrir mannréttindastefnu, sem í grunnin er stefna í anda Evrópusambandsins um bann við margpættri mismunun.

Loks verður spurt hvað myndi ávinnast, og hvort innistæða sé fyrir pví að Reykjavíkurborg setji mannréttindi í öndvegi með markvissari hætti pegar kemur að stefnumótun og ímyndarsköpun heima og heiman, með pví að flagga titlum á borð við „Mannréttindaborgin Reykjavík." Par með myndi Reykjavíkurborg skipa sér í sveit með borgum eins og Graz í Austurríki, sem er fyrsta evrópska mannréttindaborgin, Barcelona, Salzburg, Nantes, Búdapest, Gautaborg og York, sem allar eru opinberar mannréttindaborgir (Human Rights Cities 2014, 167-168). Skilgreining á mannréttindaborg (e. human right city) er sú að pað sé „sveitarfélag sem með skýrum hætti byggir stefnu sína á mannréttindum eins og pau eru útlistuð í alpjóðlegum mannréttindasáttmálum, og markar sér pannig sérstöðu á meðal annara sveitarfélaga“ (Oomen \& Baumgärtel 2012, 2). Pá hafa mannréttindaborgir að leiðarljósi grundvallargildin bann við mismunun, jafnrétti og fulla pátttöku allra. Engir leiðarvísar eða gátlistar eru pó til sem borgir geta stuðst við til pess að verða mannréttindaborgir og pær skilgreiningar sem haldið er á lofti eru fremur opnar og almennar. Oft setja mannréttindaborgir tiltekna málaflokka á oddinn og beina kröftum sínum að peim 


\section{STJÓRNSÝSLA}

sérstaklega, t.d. jafnrétti kynja, baráttu gegn kynpáttamisrétti eða réttindi fatlaðs fólks, frekar en að halda úti víðfeðmu mannréttindastarfi. Í pví sambandi má segja að Reykjavíkurborg hafi valið torsóttu leiðina, par sem mannréttindastefna og mannréttindastarf borgarinnar byggir á heildstæðri nálgun par sem öll mannlífsflóran er undir. Í samanburði við evrópskar mannréttindaborgir sker Reykjavíkurborg sig hins vegar úr að pví leyti að hér er pað borgin sem leiðir, á meðan íslensk stjórnvöld draga lappirnar.

\section{Aðferđir og gögn}

Hagnýtur tilgangur rannsóknarinnar er að skoða hvernig til hefur tekist við innleiðingu og framkvæmd mannréttindastefnu borgarinnar. Í pví sambandi verður rýnt í niðurstöður spurningakönnunar sem send var út til 353 stjórnenda hjá borginni dagana 21. febrúar til 6. mars 2014. ${ }^{3}$ Par var spurt um reynslu stjórnenda af mannréttindastefnu Reykjavíkurborgar, fordóma og stöðu jaðarsettra hópa, en par er átt við hópa sem falla undir pær mismununarbreytur sem taldar eru upp í mannréttindastefnunni frá 2013 og sem mannréttindastarf borgarinnar varðar; p.e. „uppruna, pjóðerni, litarhátt, trúarbrögð, stjórnmálaskoðun, kynferði, kynhneigð, aldur, efnahag, ætterni, fötlun, heilsufar eða annarrar stöðu.“

Svarhlutfallið í könnunni var 66\%, en alls bárust 234 svör. Til pess að fá gleggri mynd af pátttakendum var spurt um ákveðnar bakgrunnsupplýsingar. Í fyrsta lagi var spurt um kyn svarenda en par voru aðeins gefnir upp tveir svarmöguleikar, karl eða kona. ${ }^{4}$ Í ljós kom að mikill meirihluta peirra sem svöruðu voru konur, eða 70\%, á meðan karlsvarendur voru 30\%. Pessi mikli kynjamunur skýrist ef til vill að hluta pegar horft er til næstu bakgrunnsbreytu, en par var spurt á hvaða sviði fólk starfaði. Í ljós kom að yfirgnæfandi meirihluti svarenda kom af tveimur fjölmennum sviðum par sem flestir starfsmenn borgarinnar vinna og par sem konur eru í miklum meirihluta, p.e. af skóla- og frístundasviði og velferðarsviði, en 73 einstaklingar af hvoru sviði svöruðu könnuninni. Auk peirra svöruðu 18 af umhverfis- og skipulagssviði, 8 af íprótta- og tómstundasviði, 4 af menningar- og ferðamálasviði, og loks merktu 18 við valkostinn annað. Í könnuninni voru staðlaðar krossaspurningar par sem hakað var við fyrirfram skilgreind svör. Einnig var boðið upp á opnar spurningar par sem fólk gat tjáð sig frá eigin brjósti og verður svörunum sem par birtust teflt fram í bland við tölfræðiupplýsingar og prósentur til pess að gæða textann lífi og fá aukna dýpt í rannsóknina.

Auk spurningakönnunarinnar er byggt á hverskyns opinberum gögnum sem tengjast jafnréttis- og mannréttindastarfi Reykjavíkurborgar. Par eru mannréttindastefnan frá 2006 og endurskoðuð útgáfa hennar frá 2013 lykilgögn. Einnig er rýnt í tvenn drög að endurskoðaðri mannréttindastefnu Reykjavíkurborgar. Fyrri drögin, dagsett. 7. ágúst 2015, voru birt á heimasíðu mannréttindaskrifstofu 18. ágúst 2015, par sem óskað var eftir ábendingum og athugasemdum (Drög að mannréttindastefnu Reykjavíkurborgar, dags. 7. ágúst 2015), hér eftir nefnd drög 2015. Síðari drögin, dagsett 10. júní 2016 voru lögð fram á fundi borgarráðs 16. júní 2016 og síðan á fundi borgarstjórnar 21. júní 2016 (Drög að mannréttindastefnu Reykjavíkurborgar 10. júní 2016), hér eftir nefnd drög 2016. Loks er horft á lokaniðurstöðuna úr pessu tveggja ára endurskoðunarferli, pað 
er mannréttindastefnu Reykjavíkurborgar sem sampykkt var í borgarstjórn 18. október 2016 hér eftir nefnd mannréttindastefna Reykjavíkurborgar 2016 eða MR 2016. Í umfjöllun um einstök atriði stefnunnar verður almennt vísað í nýsampykkta mannréttindastefnu frá 2016. Einungis verður vísað í drögin pegar pau eru frábrugðin endanlegu útgáfunni.

Loks er byggt á gögnum frá samráðsfundi með fulltrúum grasrótarhreyfinga, sem greinarhöfundar stóðu fyrir. Fundurinn var haldinn 9. desember 2013 og par var m.a. rætt um reynslu félaganna af mannréttindastefnu Reykjavíkurborgar. Haft var samband við sjö félagasamtök sem tengjast jafnrétti kynjanna, aldri, fötlun, heilsufari, kynhneigð, trúarbrögðum og pjóðerni/uppruna. Fulltrúar tveggja félaga mættu ekki til fundarins og enginn viðbrögð bárust frá einu félagi. Fundinn sátu pví fulltrúar félagasamtaka um jafnrétti kynjanna, öldrun, kynhneigð og heilsufar, auk greinarhöfunda sem stýrðu fundinum. Dátttakendum var heitið nafnleynd og trúnaði.

\section{Horft í baksýnisspegilinn - tilurð mannréttindastefnunnar}

Aukinn áhugi og afskipti sveitarfélaga af mannréttindamálum eru að hluta tilkomin vegna pess að verkefni eins og velferðarpjónusta, skipulagsmál, málefni fatlaðs fólks og málefni leik- og grunnskóla eru nú öll í höndum sveitarfélaga. Бað er einmitt í slíkum verkum sem grundvallaratriði alpjóðlegra mannréttinda eru heimfærð upp á nærsamfélagið og fólkið sem par býr og pað er yfirleitt par sem brot á peim eiga sér stað (Human Rights Cities 2014, 11-12). Раð аð „færa mannréttindin heim“, eins og Roosevelt (1958) orðaði pað, er pví flókið og umfangsmikið verk. Eins og fram hefur komið tók Reykjavíkurborg ákveðið frumkvæði í jafnréttis- og mannréttindamálum hér á landi pegar mannréttindastefna Reykjavíkurborgar var sampykkt einróma í borgarstjórn pann 16 . maí 2006. Раð skipti sköpum að um pann gjörning náðist pverpólitísk sátt pví pegar kosið var til borgarstjórnar ellefu dögum síðar, féll sitjandi meirihluti og við tók skeið pólitísks umróts par sem fjórir meirihlutar stýrðu borginni á einu kjörtímabili. Á peim tíu árum sem liðin eru frá pví að stefnan var sampykkt hefur hún pví staðið af sér sjö borgarstjórnarmeirihluta og sex borgarstjóra.

Pví skal haldið til haga að áður en Reykjavíkurborg sampykkti mannréttindastefnu sína hafði Háskóli Íslands sett sér víðtæka mannréttindastefnu (Stefna Háskóla Íslands gegn mismunun, 2005) sem nú er fallin úr gildi, en hún stóð samhliða jafnréttisáxtlun sem snéri að kynjajafnrétti og stefnu í málefnum fatlaðra og var hún höfð til hliðsjónar pegar mannréttindastefna borgarinnar var í smíðum (Niðurstaða rannsóknarhóps um sampættingu mannréttindamála 2005, 3).

Tilkoma mannréttindastefnu Reykjavíkurborgar byggði á löngu og markvissu jafnréttisstarfi par sem fókusinn var á kynjajafnrétti. Fyrsta jafnréttisstefna borgarinnar var sett fram árið 1990. Ný jafnréttisstefna var síðan sampykkt árið 1996, en pá var jafnréttisfulltrúi kominn til starfa hjá borginni. ${ }^{5}$ Fyrstu preifingarnar í átt að pví sem kallað hefur verið „útvíkkun jafnréttisstarfs“ má sjá vorið 2003 en pá efndi jafnréttisnefnd Reykjavíkurborgar til ráostefnunnar Jafnrétti kynja - jafnrétti allra, par sem innlendir og erlendir sérfræðingar ræddu útvíkkun jafnréttisstarfs og helstu jafnréttisáherslur ólíkra 
minnihlutahópa. Sama ár var unnin rannsókn fyrir Reykjavíkurborg um minnihlutahópa, jafnrétti og kynferði sem byggði á viðtölum við fulltrúa peirra priggja minnihlutahópa sem pá voru helst í umræðunni, p.e. innflytjenda, fatlaðs fólks og samkynhneigðra. Heilt yfir sýndi rannsóknin fremur neikvæð viðhorf til ríkjandi jafnréttisorðræðu. Viðmælendur töldu að málefni peirra hópa sem pau voru í forsvari fyrir hefðu orðið útundan og kenndu kvennahreyfingunni að hluta til um pá jaðarsetningu (Berglind Rós Magnúsdóttir 2003, 14-15). Pá var pó ekki vilji fyrir pví að sameina allt jafnréttisstarf hjá borginni undir einn hatt. Pess í stað var lagt til að unnið yrði með markvissum hætti að pörfum og áherslum hvers minnihlutahóps fyrir sig.

prátt fyrir pað var settur á fót sérstakur rannsóknarhópur árið 2005, en hlutverk hans var að kanna til hlítar kosti og galla pess að sampætta allt jafnréttis- og mannréttindastarf á vegum borgarinnar (Niðurstaða rannsóknarhóps um sampættingu mannréttindamála 2005). Fjórir pættir voru lagðir til grundvallar í greiningunni: kynferði, uppruni, fötlun og efnahagur. Nú hafði hins vegar orðið einhvers konar viðsnúningur í afstöðu til útvíkkunar. Meirihluti peirra sem rætt var við voru nú fylgjandi pví að jafnréttisstarf borgarinnar yrði sampætt undir eina stefnu. Aðeins fulltrúar innflytjenda höfðu uppi efasemdir, en peir óttuðust að peirra málefni yrðu undir í útvíkkuðu jafnréttisstarfi. Đegar Jafnréttisnefnd Reykjavíkurborgar hélt árlegan landsfund jafnréttisnefnda sveitarfélaga 17. febrúar 2006, undir yfirskriftinni Jafnrétti fyrir alla, kynnti formaður nefndarinnar áætlanir um að skipta jafnréttisstefnu borgarinnar út fyrir mannréttindastefnu og premur mánuðum síðar var hún sampykkt í borgarstjórn.

Innleiðing nýrrar mannréttindastefnu kom pví í hlut nýs meirihluta. Fyrsta skrefið í pá átt var ráoning mannréttindastjóra sem gegndi embættinu í tvö ár. Í hönd fóru pólitískir umrótstímar sem ekki urðu til pess að styrkja hina nýju stefnu í sessi. Mannréttindaskrifstofa Reykjavíkurborgar var pví rekin af einni manneskju fyrstu tvö árin, og í einhverja mánuði var staða mannréttindastjóra ófyllt. Í júlí 2008 var hins vegar ráðinn nýr mannréttindastjóri sem gegnt hefur embættinu síðan. Samhliða ráðningunni var ákveðið að efla mannréttindaskrifstofuna og frá peirri ákvörðun hefur ekki verið hvikað prátt fyrir efnahagshrun, tvennar borgarstjórnarkosningar og ítrekuð meirihlutaskipti.

\section{Stjórnsýsla Reykjavíkurborgar á sviði lýðræđis- og mannréttindamála}

Mannréttindaráð er í forsvari fyrir mannréttindamálum í borginni og hefur pað starfað frá árinu 2007. Ráðið er skipað sjö pólitískum fulltrúum, kjörnum af borgarstjórn. Баð hefur eftirlit með pví að mannréttindastefnunni sé fylgt eftir og með rekstri mannréttindaskrifstofu. Pá starfa mannréttindafulltrúar á öllum sviðum borgarinnar. Hlutverk peirra er að sjá til pess í samráði við stjórnendur að mannréttindastefnu borgarinnar sé framfylgt. Aðrar stjórnsýslustofnanir og ráð sem ber að nefna í tengslum við mannréttindi og eflingu lýðræðis er stjórnkerfis- og lýðræðisráð en pað varð til í kjölfar borgarstjórnarkosninga 2014. Verkefni ráðsins er m.a. að yfirfara og einfalda stjórnkerfi borgarinnar, bæta samráð og aðgang að upplýsingum og auka pátttöku borgarbúa. Pá var embætti umboðsmanns borgarbúa stofnað vorið 2013. Embættinu er ætlað að styrkja tengslin á 


\section{STJÓRNSÝSLA}

milli borgarbúa og borgarkerfisins og auka réttaröryggi í tengslum við stjórnsýsluframkvæmd og pjónustu borgarinnar. Рá veitir umboðsmaður lagalega aðstoð vegna erinda sem snúa að mismunun og annast, með mannréttindaskrifstofu, pjónustu við pá hópa sem falla undir mannréttindastefnu Reykjavíkurborgar (Ingi B. Poulsen 2014).

Miklu skiptir að öflug tengsl séu á milli peirra sem sinna mannréttindastarfi og peirra frjálsu félagasamtaka sem mannréttindastarfið snýr að, pví í grasrótinni býr dýrmæt sérfræði- og reynslupekking um stöðu einstakra hópa sem mikilvægt er að nýta við stefnumótun og innleiðingu mannréttindastefnu. Parna virðist pó pottur brotinn hjá Reykjavíkurborg. Einhver félagasamtök, t.d. Samtökin '78 og Geðhjálp eru nú pegar með pjónustusamning við borgina sem tryggir samráð og gagnkvæmt flæði upplýsinga. Hjá öðrum félagasamtökum hafa slík tengsl hins vegar ekki verið formgerð. Á samráðsfundi sem haldin var 2013 með fulltrúum grasrótarhreyfinga kom pví fram ákall um aukin samskipti og vettvang par sem starfsemi mannréttindaskrifstofu yrði kynnt og par sem grasrótarhreyfingar gætu kynnt sig og starfsemi sína.

Athyglisverð skref sem borgin hefur stigið til pess að efla íbúalýðræði og aðkomu grasrótahreyfinga er skipan í ýmiss konar borgararáð, svo sem fjölmenningarráð, Reykjavíkurráð ungmenna fyrir 13-18 ára og öldungaráð. Ráðunum er ætlað að vera vettvangur samráðs og vera nefndum og ráðum Reykjavíkurborgar til ráðgjafar um málefni og hagsmuni peirra hópa sem undir pau heyra. Đá hefur mannréttindaskrifstofa, í samstarfi við fjölmenningarráð og aðra tengda aðlila, staðið fyrir viðamiklum fjölmenningarpingum sem haldin hafa verið á priggja ára fresti par sem fulltrúar innflytjenda koma saman og benda á möguleg úrræði til pess að auðvelda gagnkvæma aðlögun peirra og íslensks samfélags. Pá starfar ferlinefnd fatlaðs fólks í samvinnu við umhverfis- og skipulagsráð. Henni er ætlað að hafa frumkvæði að verkefnum sem stuðla að bættu aðgengi fatlaðs fólks að byggingum borgarinnar og öðrum opinberum svæðum í borgarlandslaginu (Sampykkt fyrir ferlinefnd fatlaðs fólks 2014). Yngsta nefndin sem tekur á mannréttindum er ofbeldisvarnarnefnd en til hennar var stofnað á sérstökum hátíðarfundi í tilefni af 100 ára afmæli kosningaréttar kvenna 19. júní 2015. Nefndin er viðbrögð borgarstjórnar við dæmalausum frásögnum af kynferðisofbeldi gegn konum sem birtust í lokuðum hópi á facebook á vordögum 2015 og er henni ætlað að vera borgarstjórn til ráðgjafar um aðgerðir og viðbrögð við ofbeldi í samfélaginu (Sampykkt fyrir ofbeldisvarnarnefnd Reykjavíkurborgar 2015).

Mannréttindastefnan stendur utan og ofan við einstök svið borgarinnar og skal mannréttindastarfið vera samofið allri starfsemi hennar. Hlutverk mannréttindastefnu er pví að bæta og efla opinbera pjónustu, ýta undir samvinnu og vinna gegn aðgreiningu, enda skal áhersla lögð á að finna lausnir á kerfisbundnum orsökum mismununar (Bringing Human Rigths Home 2012, 14). Pegar skoðað er hvort og pá hvernig mannréttindasjónarmið hafa verið fléttuð inn í stefnumótun borgarinnar, ber endurskoðun stjórnlaga- og lýðræðisráðs á upplýsingastefnu borgarinnar hátt. Par eru skyldur borgarinnar og réttindi borgarbúa vel útfærð, en stefnan „styður við að borgin sé leiðandi í opinberri upplýsingamiðlun, upplýsingamiðaðri pjónustu við íbúa og framsetningu upplýsinga á margvíslegu formi“ (Upplýsingastefna Reykjavíkurborgar 2015-2020, 2). Pá er áréttað 
að markmið borgarinnar sé fullt gagnsæi og virk pátttaka borgarbúa í gagnkvæmum samskiptum í opnu lýðræðislegu samfélagi. Í innkaupastefnu borgarinnar segir að gæta skuli jafnræðis peirra sem eiga viðskipti við Reykjavíkurborg og áréttað er að „,við innkaup sé auk kostnaðar tekið tillit til gæða-, umhverfis- og mannréttindasjónarmiða“ (Innkaupastefna Reykjavíkurborgar 2011). Í atvinnustefnu borgarinnar er lögð áhersla á virka pátttöku allra íbúa og að unnið sé á grundvelli hugmyndafræði sampættingar jafnréttissjónarmiða við alla stefnumótun á sviði atvinnumála (Atvinnustefna - skapandi borg 2012). Loks eru nýjar áherslur sýnilegar í heiti endurskoðaðrar menningarstefnu, „Menning er mannréttindi“, sem og í meðfylgjandi aðgerðaráætlun. Stefnan vísar til alpjóðlegra menningarlegra réttinda, sérstaklega í samningi Sameinuðu pjóðanna um efnahagsleg, félagsleg og menningarleg réttindi (Menning er mannréttindi. Menningarstefna Reykjavíkurborgar 2014).

\section{Spurningakönnun meðal stjórnenda - helstu niðurstöður}

Í pessum hluta verður rýnt í niðurstöður spurningakönnunnar sem lögð var fyrir stjórnendur hjá Reykjavíkurborg í ársbyrjun 2014. Umfjölluninni hefur verið skipt upp í fimm efnisflokka sem hér standa sem undirkaflar. Í peim verður fjallað um: pekkingu stjórnenda á mannréttindastefnunni og ákalli eftir meiri kynningu; mikilvægi pess að jaðarsettir hópar séu nefndir á nafn; notkun mannréttindastefnunar á vettvangi en par verður sérstaklega hugað að sviðum par sem hún hefur „gleymst“; hvernig kynjajafnrétti hefur reitt af í mannréttindastarfi borgarinnar, og loks verður rætt um mannaráðningar og jaðarsetta hópa.

\section{1 pekking á mannréttindastefnunni og ákall eftir meiri kynningu}

Mannréttindastefna Reykjavíkurborgar er verkfæri sem fjölmargir nýta til gagns. Pótt ekki hafi verið spurt um pað með beinum hætti, leiddi spurningakönnunin sem hér liggur til grundvallar í ljós að nokkuð almenn ánægja virðist ríkja með stefnuna meðal stjórnenda borgarinnar. Í opinni spurningu par sem fólk var spurt hverja pað teldi vera helstu kosti mannréttindastefnunnar tiltóku nokkrir einfaldar staðreyndir eins og ,að hún sé till!“‘ eða „að hún sé til staðar og stöðugt í umræðunni“, að hún væri „,skýr og aðgengileg“, að hún „tæki á málefnum allra jaðarhópa“ og „,vekti umræðu“.

Könnunin sýndi að mannréttindastefnan er vel pekkt meðal stjórnenda borgarinnar, en 59\% peirra sem svöruðu sögðust pekkja stefnuna vel eða mjög vel, á meðan 28\% svarenda sögðust pekkja hana aðeins. Pótt hlutfall peirra sem pekkja stefnuna vel sé býsna hátt, kalla pau rúmlega 40\% sem pekkja stefnuna aðeins, lítið eða ekkert á aukna kynningu, en ákall eftir meiri fræðslu um mannréttindastefnuna og mannréttindamál var lykilstef sem ítrekað kom fram. Til marks um pað tiltóku 26 einstaklingar sem svöruðu opinni spurningu um hvað mætti bæta í tengslum við framgang stefnunnar, að stefnan mætti vera sýnilegri og að hún pyrfti meiri og fjölbreyttari kynningu meðal starfsmanna á gólfi, meðal stjórnenda og meðal pólitískra fulltrúa sem koma að stjórn borgarinnar. Einhverjir nefndu mikilvægi aðgerðaáætlana og pess að hafa nákvæmlega skilgreind og tímasett markmið, sem og skilvirkara eftirlit. Loks var kallað eftir meiri og betri eftir- 


\section{STJÓRNSÝSLA}

fylgni og meira fjármagni í málaflokkinn. Sterkur samhljómur var með pessum niðurstöðum og áherslum sem fram komu á samráðsfundi með fulltrúum grasrótarhreyfinga. Á fundinum var gagnrýnt að stefnan væri mjög almenn - og jafnvel yfirborðskennd. Kallað var eftir meiri og skýrari aðgerðatengingu og áhersla lögð á mikilvægi pess að hafa nákvæmlega skilgreind og tímasett markmið sem hægt væri að mæla og ljúka. Bent var á markmið sem sett var fram í kynningarbæklingi 2013 um að vinna að „fordómalausu andrúmslofti á vinnustað par sem fatlað fólk og ófatlað vinnur saman á jafnréttisgrunni“ (Mannréttindastefna Reykjavíkurborgar 2013, 7). Spurt var hvernig borgin ætlaði að vinna að pví, hver bæri ábyrgð á verkefninu, hvað verkefnið fæli í sér, hvað pað mætti kosta og hvenær pví ætti að vera lokið.

Rúmlega helmingur svarenda, eða 52\%, sagðist hafa fengið formlega kynningu á stefnunni, en einungis 38\% vissu til pess að stefnan hefði verið kynnt fyrir starfsfólki á peirra vinnustað. Pá virðast stjórnendur ekki leita mikið til mannréttindaskrifstofu. Đó sögðust $27 \%$ svarenda hafa leitað pangað til pess að afla upplýsinga, og sama hlutfall sagðist hafa leitað til skrifstofunnar til pess að fá aðstoð og leiðbeiningar. Tæp 19\% höfðu vísað pangað einstaklingum sem til peirra höfðu leitað, en einungis $6 \%$ svarenda sögðust hafa komið á framfæri ábendingum um möguleg brot á stefnunni. Pessar niðurstöður vekja upp spurningar um tengsl eða tengslaleysi mannréttindaskrifstofunnar við svið borgarinnar, t.d. velferðarsvið par sem ítrekað koma upp stór mál sem án efa flokkast sem mannréttindamál. Í pví sambandi má nefna skort á búsetuúrræðum fyrir fatlað fólk og aðgang að ferðapjónustu fatlaðs fólks og liðveislu, sem í daglegri umræðu eru ekki endilega tengd mannréttindastefnunni. Einn svarenda tiltók sérstaklega vandann sem fylgir pví að stefnan tilheyrði ákveðinni skrifstofu, sem pá ber ábyrgð á kynningu hennar, framkvæmd og eftirfylgni í stað pess að stefnan sé sameiginleg ábyrgð allra sviða ásamt og með borgarráði, en sú sýn er mjög í anda (kynja)sampættingar.

Í tengslum við kynningu skiptir útgáfa aðgengilegs kynningarefnis sköpum. Á peim tíu árum sem stefnan hefur verið í gildi hafa tvisvar verið gefnir út myndskreyttir kynningarbæklingar. Sá fyrri kom út 2009 og í kjölfarið var í fyrsta sinn blásið til kynningarátaks par sem mannréttindastefnan var kynnt á ólíkum starfsstöðvum borgarinnar. Kynningarbæklingur var aftur gefinn út 2013 eftir að mannréttindastefnan hafði verið endurskoðuð og aðspurðir sögðust 74\% svarenda pekkja hann. Mikilvæg skref hafa verið stigin til pess að koma mannréttindastefnunni á framfæri við pá jaðarsettu hópa sem henni er einkum ætlað að pjóna. Á heimasíðu mannréttindaskrifstofu má nú nálgast stefnuna á íslensku, á íslensku táknmáli og sem auðlesið efni á íslensku, auk pess sem stefnan hefur verið pýdd á ensku, pólsku, rússnesku og litháísku.

\subsection{Mismunun nefnd á nafn}

Раð аð beina sjónum að stöðu ólíkra hópa í samfélaginu getur varpað ljósi á pað hvernig mismunun getur bæði verið stofnanabundin og kerfislæg. Раð einfalda atriði að jaðarsettur hópur sé nefndur á nafn er nokkuð sem minnihlutahópar hafa víða sett í forgang, enda staðfestir pað tilvist hópsins og gefur honum rými í almennri umræðu. Í pví sambandi má nefna að pegar unnið var að gerð Amsterdamsáttmálans, sem Evrópusam- 


\section{STJÓRNSÝSLA}

bandið innleiddi 1997, unnu fulltrúar ýmissa minnihlutahópa ötullega að pví að vera tilgreindir í sáttmálanum sem hópar sem nytu verndar (Woodward 2004). Svipuð viðhorf komu fram 2005 pegar rannsóknarhópur um sampættingu mannréttindamála ræddi við fulltrúa minnihlutahópa í tengslum við gerð mannréttindastefnu Reykjavíkurborgar (Niðurstaða rannsóknarhóps um sampættingu mannréttindmála 2005; sjá einnig Porgerður Porvaldsdóttir 2012, 161).

Vegna pess að samfélög manna eru breytingum undirorpin, má listinn yfir mismununarbreytur sem njóta verndar aldrei vera klappaður í stein heldur parf hann að vera lifandi plagg sem reglulega er uppfært (Yuval-Davis 2006, 203). Degar rýnt er í pær fimm útgáfur af mannréttindastefnu Reykjavíkurborgar sem hér eru undir, blasir við að pað hvaða mismununarbreytur eru nefndar á nafn er síhvikult ferli. Í útgáfunum frá 2006 og 2013 eru taldir upp 12 pættir sem mannréttindastefnunni er ætlað að vernda. Til samanburðar má nefna að í tillögum stjórnlagaráðs að nýrri stjórnarskrá segir að allir skuli njóta mannréttinda án mismununar, og í framhaldinu eru taldar upp 15 breytur, en upptalningunni líkur á „stöðu að öðru leyti““ ((jjóð til pings. Frumvarp til stjórnskipunarlaga 2011, 6. gr.).

Við endurskoðun mannréttindastefnu Reykjavíkurborgar 2015 og 2016 hafa orðið töluverðar hræringar varðandi pað hvað er nefnt og hverju sleppt. Í drögum frá 2015, par sem grundvöllur mannréttindastefnunnar er kynntur, voru breyturnar orðnar 16 en tungumál, kynvitund, pjóðfélagsstaða og atgervi höfðu par bæst við. Í drögunum frá 2016 hafa sex nýjar breytur bæst við, p.e. lífsskoðun, trúleysi, kyntjáning, kyneinkenni, holdafar og líkamsgerð, og eru pær pví orðnar 19 talsins. Pess ber pó að geta að fyrstu fjóra pættina mátti finna í undirköflum stefnunnar í fyrri drögum. Holdafar og líkamsgerð komu hins vegar ný inn 2016, og hafa pau nú fengið sérstakan undirkafla. Pað sem ef til vill vekur meiri athygli í drögunum frá 2016 er brotthvarf priggja mismununarbreyta, p.e. efnahags, ætternis, sem bæði voru inni 2006 og 2013, og pjóðfélagsstöðu, en sú breyta kom fyrst fram í drögunum frá 2015. Par með voru allar vísanir í stétt eða efnahagslega stöðu formlega afmáðar úr mannréttindastefnu borgarinnar. Áður höfðu pessar breytur haft nokkuð einkennilega stöðu. Efnahagur var t.d. frá upphafi listaðar í kaflanum um grundvöll stefnunnar, en hefur aldrei fengið sjálfstæða undirkafla par sem útlistað er hvernig borgin sem stjórnvald, atvinnurekandi, veitandi pjónustu og samstarfsaðili hyggst takast á við efnahagslega mismunun. Brotthvarf efnahags og pjóðfélagsstöðu tónar vel við regluverk Evrópusambandsins, pví pótt stéttarstaða sé iðulega ávísun á ójafnrétti og samfélagslega mismunun, er hún hvergi nefnd í tilskipunum Evrópusambandsins sem mismunun sem taka parf á (Verloo 2006, 216). Athygli vekur að í lokayfirferð endurskoðunarferlisins hefur stéttarhugtakinu verið kippt inn, og er pað í fyrsta skipti sem hugtakið stétt er notað í mannréttindastefnu borgarinnar. Í fyrsta kafla, par sem fjallað er um grundvöll stefnunnar, segir nú:

Mannréttindastefnan ... miðar að pví að allar manneskjur fái notið mannréttinda án tillits til uppruna, pjóðernis, stéttar, tungumáls, litarháttar, trúarbragða, lífs-, stjórnmálaskoðana, trúleysis, kyns, kynhneigðar, kynvitundar, kyntjáningar, kyneinkenna, aldurs, fötlunar, 


\section{STJÓRNSÝSLA}

holdafars, líkamsgerðar, heilsufars, atgervis eða annarrar stöðu (Mannréttindastefna Reykjavíkurborgar 2016, 1. gr.)

Til pess að árétta áhrifamátt pess að mismununarbreytur eru nefndar á nafn hjá borginni má segja frá pví að spurt var hvort að framsetning mannréttindastefnunnar hefði vakið athygli svarenda á aðstöðu tiltekinna hópa sem pau hefðu ekki leitt hugann að áður. Alls svöruðu 57 pessari spurningu játandi og í kjölfarið tilgreindu 42 svarendur aðstöðu hvaða hópa mannréttindastefnan hefði vakið athygli peirra á. Sá flokkur sem oftast var nefndur er fötlun, en 12 einstaklingar tilgreindu hann sérstaklega. Aldur fylgdi svo í kjölfarið, með tíu tilnefningar. Næstar komu breyturnar heilsufar og pjóðerni/uppruni, en átta nefndu hvorn flokk fyrir sig. Dví er ljóst að mannréttindastefnan og kynningarefni og fræðsla henni tengd hefur vakið einhverja til vitundar um jaðarsetta hópa sem áður höfðu fallið í skuggann.

Loks má segja frá pví að opnað var fyrir umræðu um transfólk í jafnréttisfræðslu í skólum með endurskoðaðri útgáfu mannréttindastefnunar frá 2013. Par segir að allt uppeldis- og tómstundastarf, menntun og fræðsla skuli taka mið af pví „að pátttakendur geti verið samkynhneigðir, tvíkynhneigðir, transgender eða gagnkynhneigðir.“ Og kveðið er á um að: „Ólíkar kynhneigðir fólks séu ræddar kinnroðalaust“ (6.3.1. MR 2013). Starfsmaður sem starfaði sem verkefnastjóri jafnréttis á skóla- og frístundasviði sagði frá pví að ítrekað hefði komið upp að kennarar segðust fúsir til pess að ræða ólíkar kynhneigðir og transfólk, en peir óttuðust að foreldrar yrðu ósáttir við slíka umræðu. †á skipti sköpum að geta sagt: „já en mannréttindastefna Reykjavíkurborgar stendur með pér í pvi““ ${ }^{6}$ Petta er skýrt dæmi um hvernig mannréttindastefnan hefur verið notuð með markvissum hætti til pess að staðfesta tilvist lítils, jaðarsetts hóps og gefa honum rými í almennri umræðu. Athygli vekur að slíkar áherslur hafa að einverju leyti verið tónaðar niður í mannréttindastefnunni 2016. Par kemur fram að allt „uppeldis- og tómstundastarf, menntun og menningarstarf taki mið af pví að pátttakendur geti verið hinsegin“ (7.3.1. MR 2016). Í drögunum frá 2015 er kveðið á um að „ólíkar kynhneigðir, kynvitund, kyntjáning og kyneinkenni fólks séu rædd á opinskáan og fordómalausan hátt“ (6.3.1. Drög 2015). Í mannréttindastefnunni 2016 er hins vegar pessi almenna yfirlýsing: „Margs konar fjölskyldugerðir á að ræða á opinskáan og fordómalausan hátt.“ Og að lokum er pó kveðið á um að skólastjórnendur og ábyrgðarfólk skóla- og frístundastarfs eigi að sjá til pess að „,nemendur hljóti hinsegin fræðslu“ enda sé pað stefna borgarinnar „að hinsegin fólk njóti virðingar“ (7.3.1. MR 2016).

\subsection{Mannréttindastefnan sem tæki á vettvangi}

Næsta spurning sem rýnt verður í snýr að notkun mannréttindastefnunnar á vettvangi. Taldir voru upp tíu verkpættir og spurt hvort mannréttindastefnan væri höfð til hliðsjónar við úrlausn peirra. Til einföldunar má gróflega skipta verkpáttunum í tvennt. Fyrri flokkurinn snýr að mannaráðningum og starfsmannahaldi, en síðari flokkurinn snýr að úthlutun fjármagns, en par er bæði um að ræða kaup og kjör, og úthlutun styrkja og pjónustu til einstaklinga, félagasamtaka og stofnana. Auk pess voru tveir pættir sem 


\section{STJÓRNSÝSLA}

ekki falla undir tveggjaflokka kerfið. Annars vegar var verkpátturinn „,við undirbúning stefnumótunar“ en par sögðu 62\% að mannréttindastefnan væri höfð til hliðsjónar. Hins vegar var spurt um „skipulagsmál“住 en par sagði einungis 31\% hafa stuðst við stefnuna. Pegar nærumhverfið er skipulagt er mikilvægt að muna eftir kynja- og mannréttindasjónarmiðum. Í mannréttindastefnunni frá 2016 er pví áréttað að skipulagsmál séu jafnréttismál og að borgarmyndin eigi að taka „tillit til allra kynja í skipulagi“ (2.1.4. MR 2016). Đá er kveðið á um að opinberar byggingar eigi „að vera aðgengilegar fyrir alla, óháð fötlun“ (4.3.2. MR 2016) enda verða aðgengismál og skipulagsmál ekki sundur slitin.

Snúum okkur pá að meginflokkunum tveimur. Eins og áður sagði snýr fyrri flokkurinn að mannaráðningum og starfsmannahaldi, og par er ástandið býsna gott. Tæp 83\% tiltóku pannig að stefnan væri höfð til hliðsjónar við mannaráðningar, 63\% sögðu að hún væri nýtt í tengslum við endurmenntun og pjálfun starfsfólks, en tæp 49\% sögðu að hún væri nýtt í tengslum við skipan í stöður og framgang í starfi. Í pví sambandi ber að nefna að starfsmannastefna Reykjavíkurborgar er frá 2001, og pví er hún eldri en mannréttindastefnan, en prýstingur er á að uppfæra hana.

pegar rýnt er í síðari flokkinn, sem snýr að úthlutun fjármagns, verða niðurstöðurnar hins vegar sláandi. Einungis $23 \%$ svarenda sögðu stefnuna nýtta við úthlutun fjármagns, en tæplega helmingur, eða 48\%, töldu að par ætti spurningin ekki við. Fjarvera mannréttindastefnunar vekur sérstaka athygli í ljósi pess að markvisst hefur verið unnið að kynjaðri fjárlagagerð í borginni frá 2011 og á málpingi um kynjaða fjárhags- og starfsáætlun sem Reykjavíkurborg stóð fyrir 17. september 2015 voru ræddar mögulegar leiðir til pess að útvíkka starfið, pannig að allir hópar sem mannréttindastefnan nær til séu undir. Бá sögðu einungis 32\% að stefnan væri höfð til hliðsjónar við ákvarðanir um kaup og kjör, en tæp 45\% sögðu að spurningin ætti ekki við, sem er athyglisvert í ljósi pess að kynbundinn launamunur er eitt stærsta og erfiðasta úrlausnarefnið í jafnréttisstarfi samtímans, en hjá borginni eru til gögn um kynbundinn launamun allt aftur til ársins 1995. Í könnun sem Félagsvísindastofnun Háskóla Íslands vann fyrir Reykjavíkurborg kom fram að kynbundinn launamunur var 4,1\% árið 2013 og 3,5\% árið 2014 meðal starfsfólks sem var í að minnsta kosti 70\% starfi, ,eftir að tekið hefur verið tillit til aldurs, starfsaldurs, starfaflokks, starfshlutfalls, yfirvinnustunda og vinnustunda utan venjulegs vinnutíma“ (Helgi Guðmundsson \& Guðbjörg Andrea Jónsdóttir 2015, 7). Athygli vekur að í mannréttindastefnunni frá 2013 er ekki kveðið á um pað með skýrum hætti að útrýma skuli kynbundunum launamun. Pó segir: „Konur og karlar skulu njóta sambærilegra kjara og réttinda“ (2.2.3. MR 2013). Einnig er talað um að útrýma beri launaleynd, par sem hún sé ein af uppspettum kynbundins launamunar. Í drögunum frá 2015 er enn áréttað að „launaleynd sé ein af uppsprettum kynbundins launamunar og að henni beri pví að útrýma ... rétt eins og kynbundnum launamun ${ }^{67}$ (2.2.3. Drög 2015). Í mannréttindastefnunni frá 2016 er talað um ,að aðstæður sem bjóði uppá launaleynd séu ein af uppsprettum kynbundis launamunar og pví beri að útrýma peim“ (2.2.3. MR 2016). Lokasetningunni úr drögunum frá 2015, sem undirstrikuð er að framan, hefur hins vegar verið kippt út (2.2.3. Drög 2016).

pegar kom að úthlutun fjármagns og pjónustu til einstaklinga, hópa eða félagasam- 
taka sögðu tæp 33\% að stefnan væri höfð til hliðsjónar, á meðan 56\% töldu spurninguna ekki eiga við. Degar spurt var um úthlutun styrkja og gerð pjónustusamninga breikkaði bilið enn, en einungis 26\% sögðu að stefnan væri pá höfð til hliðsjónar á meðan 59\% sögðu spurninguna ekki eiga við. Af pessu má ráða að pörf virðist á aukinni kynningu á stefnunni - en sér í lagi parf pó að auka meðvitund um að stefnan parf alltaf að vera til hliðsjónar - í öllum málaflokkum, og við alla ákvarðanatöku - og sérstaklega er pörf á að beita mannréttindagleraugunum pegar kemur að úthlutun fjármagns.

Í mannréttindastefnu Reykjavíkurborgar 2016 eru ýmis ný málefni sett á dagskrá. Í 12. kafla, par sem fjallað er um borgina sem samstarfsaðila, hefur hugtakinu verkkaupi nú verið bætt við. Đar er tekið fram að „öllum nefndum og ráðum borgarinnar sem úthluta styrkjum“ beri að fara eftir mannréttindastefnunni við úthlutun peirra (12.2. MR 2016). Dá segir: „Reykjavíkurborg gerir pær kröfur til peirra fyrirtækja sem hún kaupir pjónustu af að pau virði mannréttindi peirra sem pau pjónusta í nafni borgarinnar og mismuni ekki starfsfólki sínu“ (12.5. MR 2016). Ennfremur hvetur borgin „pau fyrirtæki sem hún kaupir pjónustu af til að móta sér mannréttindaáætlun með mælanlegum markmiðum” (12.6. MR 2016). Pessi ákvæði eiga vafalítið eftir að valda pólitískum titringi, en bæði komust pó óbreytt úr tvennum drögum og yfir í nýsampykkta mannréttindastefnu. Раð vekur athygli að hér er hugtakið keðjuábyrgð ekki notað, en pví er ætlað að tryggja að peir sem vinna hjá verktökum, undirverktökum eða starfsmannaleigum, njóti réttinda og kjara í samræmi við lög og kjarasamninga sem gilda hér á landi. Pann 29. apríl 2016 sampykkti innkauparáð Reykjavíkurborgar hins vegar að setja ákvæði í alla samninga við verktaka sem starfa á vegum borgarinnar til að sporna gegn mögulegu mansali (Innkauparáð. Fundur nr. 370).

рá er pað nýlunda að umhverfis- og öryggismál séu skilgreind sem mannréttindamál (kaflar 10 og 11 MR 2016). Dví skal pó haldið til haga að í tillögum stjórnlagaráðs að nýrri stjórnarskrá bar mannréttindakaflinn titilinn „Mannréttindi og náttúra“, og í undirköflum var fjallað um náttúru Íslands og náttúruauðlindir (एjóð til pings. Frumvarp til stjórnskipunarlaga 2011, II. kafli 33. og 34. gr.). Í mannréttindastefnu Reykjavíkurborgar 2016 eru umhverfis- og öryggismál sett á dagskrá með nokkuð almennum en yfirgripsmiklum hætti, og án pess að nákvæmlega sé útfært hvar, hvenær og hvernig peim skuli haldið á lofti í borgarsamfélaginu. Orð eru hins vegar til alls fyrst og lög og stefnur geta verið mikilsverð tæki til pess að koma málum á dagskrá og breyta pannig hugsunarhætti og hegðun fólks.

\subsection{Afdrif kynjajafnréttis í útvíkkađri mannréttindastefnu}

Í spurningakönnuninni var sérstaklega hugað að afdrifum kynjajafnréttis. Spurt var: „Telur pú að áherslan á kynjajafnrétti hafi breyst við innleiðingu mannréttindastefnunar?" Petta er brýn spurning par sem áður höfðu komið fram pungar áhyggjur af pví að útvíkkun jafnréttisstarfs myndi pýða að kynjabreytunni yrði ýtt til hliðar (Dorgerður Porvaldsdóttir 2012, 221-224). Pegar lagt var upp í pá vegferð að útvíkka jafnréttisstarf borgarinnar var lögð pung áhersla á að kynjajafnrétti yrði áfram miðlægt í allri stefnumótun. Til marks um pað var sérstaklega tekið fram að greina pyrfti stöðu kvenna annars 


\section{STJÓRNSÝSLA}

vegar og karla hins vegar innan hvers minnihlutahóps (Mannréttindastefna Reykjavíkurborgar 2006 og 2013). Fyrir útvíkkun jafnréttisstarfsins kom ítrekað fyrir að erindi par sem kynjajafnrétti skaraðist við málefni innflytjenda, hinsegin fólks eða fatlaðs fólks rötuðu inn á borð jafnréttisnefndar, sem pá hafði hvorki umboð né verkfæri til pess að takast á við pau með fullnægjandi hætti (Thorvaldsóttir \& Einarsdóttir 2011, 112). Меð tilkomu mannréttindastefnunnar, par sem fleiri hópar voru teknir inn, var eins og almenningur yrði jákvæðari gagnvart fræðslu og umræðu um jafnréttismál (Dorgerður Porvaldsdóttir 2012, 251). Mikilvægi kynjabreytunnar var sérstaklega áréttað í kynningarbæklingi sem út kom 2009, en par birtist kynjajafnrétti sem rauður práður sem vefur sig í gegnum bæklinginn og samtvinnast öllum öðrum mismununarbreytum (Mannréttindastefna Reykjavíkurborgar 2009). Dótt sú myndlíking hafi horfið í kynningarbæklingnum frá 2013, virðast áherslur á mikilvægi kynjajafnréttis pó enn halda velli og í mannréttindastefnunni frá 2016 er áhersla á kynjajafnrétti enn ítrekuð í öllum málaflokkkum. Nú er hins vegar rætt um öll kyn í stað beggja kynja áður par sem venjubundnar skilgreiningar á karlkyni og kvenkyni eigi ekki alltaf við.

Aðspurð sögðust tæp 26\% peirra sem svöruðu spurningakönnunni telja að áhersla á kynjajafnrétti hafi aukist við innleiðingu mannréttindastefnunnar, einungis $6 \%$ töldu áhersluna á kynjajafnrétti hafa minnkað, tæp 39\% töldu að áherslan hafi haldist óbreytt, en um 30\% svarenda höfðu ekki skoðun á málinu. Pessar tölur má taka sem vísbendingar um að áherslur á kynjajafnrétti hafi ekki farið halloka með nýrri stefnu og nýju stofnanaumhverfi. Hér er pó rétt að gera örlítinn fyrirvara og rifja upp áhugaverðar niðurstöður sem fram komu í skýrslu um stöðu og próun jafnréttismála við Háskóla Íslands árin 2003-2007 (Auður Magndís Leiknisdóttir ofl. 2009). Par komu fram mjög ólíkar skoðanir á pví hvernig til hefði tekist með jafnréttisstarf í Háskólanum og var merkjanlegur munur á almennum stjórnendum skólans, sem töldu hann vera í fararbroddi í jafnréttismálum, og fólki sem unnið hafði að málaflokknum innan skólans, en pau voru á pví að jafnréttisstarfið væri í mikilli lægð. Í ljósi pessara andstæðu skoðana er pví ástæða til að taka jákvæðum niðurstöðum varðandi stöðu kynjajafnréttis hjá Reykjavíkurborg með ákveðnum fyrirvara, par sem lítið er vitað um bakgrunn svarenda og pekkingu peirra á málaflokknum. Í opnum spurningum kom til að mynda ítrekað fram óánægja með kynbundinn launamun. Pegar spurt var hvað mætti betur fara í tengslum við framkvæmd stefnunnar, svaraði einn að „borgin ætti að jafna laun á milli sviða borgarinnar, pannig að kynjamisrétti komi ekki svona skýrt fram í launaumslaginu.“ Og annar sagði: „Fólki er mismunað eftir kyni hjá Reykajvíkurborg, t.d. er viðvarandi launamisrétti á milli kynja. Á meðan svo er er mannréttindastefnan ekki að virka.“

\subsection{Mannaráđningar og jađarsettir hópar}

раð er áhugavert að skoða hvernig borginni hefur tekist að rækta hlutverk sitt sem atvinnurekanda gagnvart fólki úr jaðarsettum hópum. Í spurningakönnuninni var spurt: „Hefur pú ráðið til pín starfsfólk sem tilheyrir jaðarsettum hópum?“ Afgerandi meirihluti, eða 77\% svarenda, svaraði spurningunni játandi en einungis 17\% sögðu nei. Баð kom á óvart hversu hátt hlutfall stjórnenda taldi sig hafa ráðið starfsfólk sem tilheyrir 
jaðarsettum hópum og hversu öruggir peir voru í tengslum við slíkar ráðningar. Hér hefði pví verið áhugavert að kafa dýpra og fá nánari útlistanir á pví hvaða jaðarsettu hópa var um að ræða. Aðeins var snert á pví pegar spurt var hvort fólk hefði fundið til óöryggis í starfi gagnvart nýjum áskorunum, eins og peim að ráða til starfa fólk úr jaðarsettum hópum. Rúmlega 19\% svöruðu játandi, og í kjölfarið svöruðu 25 einstaklingar opinni spurningu par sem peir útlistuðu hvaða aðstæður hefðu kallað fram óöryggi. Tvær flokkatvennur voru mest áberandi. Annars vegar fundu svarendur til óöryggis í tengslum við mannaráðningar vegna uppruna eða pjóðernis starfsmanna og hins vegar nefndi fólk óöryggi gagnvart fötlun eða heilsufari starfsfólks.

Í fyrri flokknum snérust svörin fyrst og fremst um óöryggi gagnvart innflytjendum og par voru vandamálin tengd tungumálakunnáttu og menningarlegum mismun. Einn lýsti t.d. áhyggjum sínum af pví „hvort einstaklingur gæti sinnt verkefninu vegna tungumálaörðugleika.“ Annar tiltók ólík gildi og sagðist ekki geta gengið að pví vísu „hvort viðkomandi skildi hluti á sama hátt og aðrir pjóðernishópar." Í framhaldi af umræðunni um innflytjendur má geta pess að síðar í könnunni var spurt hvort fólk hefði notað sérstaka móttökuáætlun sem ætluð er fyrir mótttöku nýrra starfsmanna af erlendum uppruna. Mikill meirihluti, eða 71\%, svaraði peirri spurningu neitandi. Aðspurð hvers vegna, sögðu tæp 53\% að pau hefðu ekki vitað að slík móttökuáætlun væri til, sem aftur er áminning um mikilvægi kynningar og fræðslu, pví vandaðar stefnur og áætlanir eru gagnslitlar ef fólk veit ekki af peim. Tæp 44\% svarenda sögðust hins vegar aldrei hafa ráðið erlent starfsfólk, sem er athyglisvert í ljósi pess að um 14.000 innflytjendur voru búsettir í borginni 1. janúar 2014 (Hagstofa Íslands 2014). Í fyrsta kafla mannréttindastefnunnar frá 2016, par sem fjallað er um Reykjavíkurborg sem atvinnurekanda, er skýrt kveðið á um að starfsfólk borgarinnar skuli endurspegla pað „margbreytilega samfélag sem borgin er“ (1. MR 2016) Í kaflanum um uppruna og pjóðerni er lögð áhersla á að fjölga skuli innflytjendum í störfum borgarinnar og í áhrifastöðum (9.2. MR 2016) og tekið er fram að pekking og menntun fólks af erlendum uppruna skuli metin að verðleikum að fólk skuli njóta „leiðsagnar við að meta pá menntun sem pað hefur aflað sér“ (9.2.2. MR 2016).

Hinn flokkurinn sem veldur óöryggi og gjarnan var nefndur tengdist fötlun og/eða heilsufari. Par mátti finna einhver svör sem lýsa almennum fordómum, hræðslu og óöryggi gagnvart fötluðu fólki og fólki með langvarandi heilsubrest, og par voru geðraskanir ítrekað nefndar. Pá var talsvert um að fólk nefndi fjármagn sem takmarkandi pátt. Í pví sambandi var talað um fjármagn vegna túlkapjónustu og fjármagn til pess að ráða fólk með skerta starfsgetu. Einn sagði; „Vont að vilja ráða fatlað fólk til starfa sem geta ekki tekið fulla ábyrgð á starfinu en geta svo hæglega sinnt starfinu að hluta. Баð vantar hvatningu til að geta ráðið starfsfólk með fötlun, sérstaklega fjárhagslega.“ Og annar sagði; „, „аð vantar fjármagn til að veita t.d. fötluðum einstaklingum með skerta starfsgetu störf. Margir einstaklingar gætu unnið afmörkuð störf í leikskólum en leikskólarnir geta ekki greitt pau laun af mjög svo pröngum fjárhagsramma.“

Parna parf borgin augljóslega að bregast við pannig að ekki myndist gjá milli yfirlýstra markmiða og pess sem mögulegt er að standa við og framkvæma innan pess 
fjárhagsramma sem stofnunum borgarinnar er settur. Á pessu er tekið með afgerandi hætti í nýrri mannréttindastefnu, sem augljóslega er innblásin af Samningi Sameinuðu pjóðanna um réttindi fatlaðs fólk sem Alpingi fullgilti 2016. Útgangspunkturinn par er sá skilningur að fötlun megi rekja ,til víxlverkunar milli einstaklinga með skerðingar og viðhorfa sem ríkja í samfélaginu til peirra, og koma í veg fyrir virka samfélagspátttöku peirra“ (4. MR 2016). Gert er ráð fyrir að borgin taki á sig auknar skyldur pegar kemur að atvinnumálum fatlaðra. Til að mynda er rætt um að veita „fötluðu fólki tíma til aðlögunar í nýju starfi“ (4.2. MR 2016) og að stuðla skuli að pví að „færni og geta fatlaðs fólks sé viðurkennd í ríkari mæli, sem og framlag pess til vinnustaða sinna og vinnumarkaðarins í heild” (4.2.1. MR 2016). Pá einsetur borgin sér „að ráða til starfa ... pað hlutfall starfsfólks með skerta starfsgetu sem endurspeglar hlutfall peirra í samfélaginu“ og að „hlutastörf séu í boði““ (4.2.1. MR 2016).

petta eru vissulega áskoranir til stjórnenda borgarinnar sem vinna, eins og könnunin leiddi í ljós, undir stöðugum kröfum um skilvirkni, aðhald og sparnað. Peir virðast pví ítrekað settir í pá stöðu að velja á milli pess að framfylgja mannréttindastefnunni eða halda sig innan fjárhagsramma.

\section{Niðurlag}

Reykjavíkurborg hefur verið óhrædd við að taka frumkvæði á landsvísu. Hún útvíkkaði jafnréttisstarfið árið 2006 og skipti (kynja)jafnréttisstefnu borgarinnar út fyrir víðtæka mannéttindastefnu. Pegar stefnan var endurskoðuð árið 2013 var bætt inn ákvæði um að unnið skuli gegn margpættri mismunun. Par er borgin mikilvæg fyrirmynd fyrir löggjafarvaldið, par sem margpætt mismunun er hvergi nefnd í fyrirliggjandi frumvarpsdrögum sem nefnd voru hér að framan, p.e. frumvarpi um jafna meðferð á vinnumarkaði og frumvarpi um jafna meðferð óháð kynpætti eða pjóðernisuppruna. Í mannréttindastefnu Reykjavíkurborgar sem sampykkt var í borgarstjórn 18. október 2016, eftir tveggja ára endurskoðunarferli, eru enn boðaðar nýjar áherslur sem ganga lengra en landslög. Dæmi um pað er aukin áhersla á mannréttindi í viðskiptum. Đá er pað nýlunda að umhverfis- og öryggismál séu skilgreind sem mannréttindamál.

Mannréttindastefnu Reykjavíkurbogar er ætlað að vera framsækinn leiðarvísir í starfi borgarinnar í jafnréttis-, fjölmenningar- og mannréttindamálum. Фað sem hindrar próun staðbundinna mannréttinda er veik staða peirra á vettvangi innanlandsstjórnmála. Á meðan stefnumótun borgarinnar á sviði mannréttinda, starfsmannamála, atvinnumála, fjölmenningar og kynjajafnréttis rímar vel við löggjöf Evrópusambandsins um bann við mismunun, hefur gætt tregðu hjá ríkisvaldinu. Ísland hefur, eitt vestrænna ríkja, ekki innleitt löggjöf um bann við mismun, nema á sviði kynjajafnréttis. Misræmið á milli landslaga og sveitarstjórnarstigsins hefur pví veikt gerendamátt mannréttindastefnunnar og möguleika borgarinnar til að halda uppi öflugu mannréttindastarfi, pví pótt mannréttindastefnan sé metnaðarfull og skýr, pá varða brot á henni ekki við landslög og pað hefur hindrað að hún sé innleidd af fullum punga. Í staðinn stendur hún sem falleg orð á pappír sem erfitt hefur reynst að raungera inni á ólíkum starfssviðum borgarinnar.

pegar kemur að mannréttindum og margpættri mismunun er mikilvægt að efla 


\section{STJÓRNSÝSLA}

tengslin á milli mannréttindaskrifstofu og peirra frjálsu félagasamtaka sem mannréttindastefnan snýr að. Hluti af slíkri samvinnu er söfnun jafnréttisgagna - par sem stefnumótun og innleiðing mannréttindastefnu verður markvissari með meiri og betri upplýsingum um stöðu jaðarsettra hópa í borginni. Miklu skiptir að slík vinna gangi í báðar áttir, p.e. að frumkvæði komi bæði að ofan - (,top down“ nálgun) og að pað spretti úr grasrótinni og af jaðrinum („,bottom up“ nálgun). Nú einkennist stefnumótun borgarinnar af pólitískum vilja til aukins gagnsæis, virkari pátttöku íbúa og betri og aðgengilegri upplýsingagjöf peim til handa. Í mannréttindastefnunni frá 2016 kemur fram ný áhersla á frelsi til tjáningar bæði starfsmanna og pjónustupega borgarinnar um pað sem betur má fara. Slíkum áherslum parf að fylgja vilji stjórnenda og embættismanna til að hlusta og bregðast við ábendingum. Stjórnendur purfa einnig að hafa nauðsynlegt fjármagn og mannafla auk vel útfærðar stefnumörkunnar með skýrum grunngildum til að starfsfólki sé ljóst eftir hvaða viðmiðum pað á að vinna. Pá skiptir sköpum að borgin hefur innleitt kynjaða fjárhags- og starfsáætlun sem vilji er til að víkka út pannig að hún taki á öllum hópum sem mannréttindastarfið nær til, pví fjármagn ræður.

pegar mannréttindastefnan er skoðuð út frá gagnrýni Kantola (2014), sem heldur pví fram að með útvíkkun jafnréttisstarfs sé hætta á að jákvæðar, fyrirbyggjandi aðferðir, eins og sértækar aðgerðir og kynjasampætting, víki fyrir einföldu banni við mismunun, er pað niðurstaða okkar að slíkt hafi ekki gerst hjá Reykjavíkurborg. Mannréttindastefnan er annað og meira en einfalt bann við mismunun. Í henni eru margskonar ákvæði sem lúta að aðgerðaskyldu borgarinnar til pess að taka á kerfislægri mismunun gagnvart ólíkum minnihlutahópum. Innleiðing stefnunnar á ólíkum sviðum borgarsamfélagsins hefur hins vegar reynst vandasöm. Pannig leiddi rannsóknin í ljós að áherslur borgarinnar sem eru í anda sampættingar eða sértækra aðgerða virðast oft „gleymast“ pegar kemur að úthlutun fjármagns og í skipulagsmálum. Eins virðast mannréttindasjónarmið jafnvel purfa að víkja fyrir fjárhagssjónarmiðum pegar kemur að mannaráðningum fólks úr jaðarhópum. Prátt fyrir fögur fyrirheit um annað í mannréttindastefnunni, kom skýrt fram að par stendur fatlað fólk, innflytjendur og langveikt fólk höllum fæti af pví pau purfa oft meiri og dýrari aðlögun og pað virðist lítið svigrúm til pess að ráða inn fólk með skerta starfsgetu. Stjórnendur standa pví frammi fyrir misvísandi kröfum, annars vegar eiga peir að sýna aðhald og sparnað í rekstri og hins vegar purfa peir að taka mið af inntaki mannréttindastefnunnar, mæta pörfum ólíkra jaðarhópa og taka á margpættri mismunun.

prátt fyrir pessa ágalla hefur Reykjavíkurborg margt til að bera til að ganga til liðs við evrópskar borgir sem pegar flagga titlinum mannréttindaborg. Pótt margir stjórnmálaflokkar hafi komið að stjórn borgarinnar hefur náðst pólitísk samstaða um mikilvægi málaflokksins, markmið og leiðir. Pá hefur mannréttindastarfið verið stofnanavætt. Fallegur titill á borð við „Mannréttindaborgin Reykjavík“ má hins vegar aldrei verða eins og sparikjóll sem dreginn er upp við hátíðleg tækifæri en síðan lokaður inni í skáp pess á milli. Titlinum fylgja bæði skyldur og ábyrgð og fjármagn og sérfræðipekking verða að fylgja markmiðum. Degar rýnt var í pær hindranir og erfiðleika sem evrópsku mannréttindaborgirnar höfðu staðið frammi fyrir, voru efnahagslegar hindranir af ýmsu tagi 
efstar á blaði (Human Rights Cities 2014, 173-174). Nærtæk dæmi úr íslensku umhverfi um mannréttindamál sem kosta, er umræða um fríar skólamáltíðir, aðgengi að viðunandi búsetuúrræðum fyrir fatlað fólk, aðgangur að ferðapjónustu fatlaðs fólks og liðveislu, sem og úrræðaleysi í tengslum við NPA - eða notendastýrða persónulega aðstoð fyrir fatlað fólk, sem enn er í skötulíki pví fjármuni skortir.

Lög og stefnur, í pessu tilfelli mannréttindastefna Reykjavíkurborgar, geta hins vegar verið tæki til breytinga. Með framsækinni lagasetningu og stefnumótun er hægt að marka nýjar áherslur og koma málum á dagskrá sem ekki hafa verið í almennri umræðu og breyta pannig hugsunarhætti og hegðun fólks. Tilurð mannréttindastefnunnar er skýr yfirlýsing frá borgaryfirvöldum um að jafnréttis- og mannréttindamál skuli vera grundvallarstef í stjórn og stefnumótun borgarinnar. Einn aðalhvatinn fyrir ritun pessarar greinar er sú trú að mikilvægt sé að slíkar niðurstöður séu kynntar á víðara grunni en bara innan borgarkerfisins, par sem reynslan frá borginni getur verið lærdómsrík fyrir önnur sveitarfélög - og fyrir ríkisvaldið sem nú áætlar að innleiða nýja löggjöf og nýtt stofnanalandslag í tengslum við jafnrétti í víðum skilningi og bann við mismunun.

\section{Aftanmálsgreinar}

1 Dorgerður vann sinn hluta rannsóknarinnar fyrir styrk frá EDDU Öndvegissetri.

2 Guðbjörg Lilja starfaði sem sérfræðingur á mannréttindaskrifstofu Reykjavíkurborgar frá júlí 2013febrúar 2014.

3 Greinarhöfundar sömdu og hönnuðu spurningakönnunina í nánu samráði við Halldóru Gunnarsdóttur, sérfræðing á sviði kynjajafnréttis á Mannréttindaskrifstofu, og er henni hér með pökkuð samvinnan. •að var hins vegar Mannauðsdeild Reykjavíkurborgar sem sendi könnunina út og vann úr niðurstöðunum. Við fengum síðan frjálsar hendur til pess að vinna áfram með pau gögn og pökkum við fyrir pað.

4 Í hádegisfyrirlestri RIKK sem haldin var 21.11.2014, par sem greinarhöfundar kynntu helstu niðurstöður könnunarinnar kom fram gagnrýni á pað að aðeins voru tveir flokkar í boði pegar spurt var um kyn, og ekki gefin priðji valkostur. Dessu var sannarlega velt upp pegar spurningakönnunin var búin til, en höfundar porðu ekki að rugga bátnum og völdu öruggu leiðina með aðeins tveimur valkostum, sem eftir á að hyggja var misráðið, pví könnunina hefði mátt nota sem tæki til pess að opna umræðu um transfólk og aðra pá sem ekki falla undir tveggja kynja kerfið.

5 рað var deildarstjóri skjaladeildar hjá Reykjavíkurborg, Halla María Árnadóttir, sem gróf petta upp fyrir milligöngu Halldóru Gunnarsdóttur sérfræðings á mannréttindaskrifstofu og er peim báðum pakkað fyrir aðstoðina.

6 Dessi frásögn er annars vegar byggð á stuttu óformlegu samtali sem fram fór í nóvember 2014 og hins vegar samræðum í einkaskilaboðum á samskiptavefnum facebook.

7 Undirstrikun er höfunda.

\section{Heimildaskrá}

Atvinnustefna Reykjavíkurborgar - skapandi borg 5. júní 2012. Sótt 14. október 2015 á http://reykjavik. is/sites/default/files/ymis_skjol/skjol_svida/ATVINNUSTEFNA(low)_1.pdf

Auður Magndís Leiknisdóttir, Ásdís Aðalbjörg Arnalds og Friðrik H. Jónsson (2009). Staða og próun jafnréttismála við Háskóla Íslands 2003-2007. Reykjavík: Félagsvísindastofnun Háskóla Íslands.

Berglind Rós Magnúsdóttir (2003). Minniblutahópar, kynferơi og jafnrétti. Sótt 14. október 2015 á http:// gamli.reykjavik.is/upload/files/Minnihlutahópar - kynferði og jafnrétti.pdf

Borchorst, A., Freidenvall, L., Kantola, J., Reisel, L. og Teigen, M. (2012). „Institutionalizing Intersec- 


\section{STJÓRNSÝSLA}

tionality in the Nordic Countries: Anti-Discrimination and Equality in Denmark, Finland, Norway and Sweden", í A. Krizsan, H. Skjeie og J. Squires (ritstj.), Institutionalizing Intersectionality. The Changing Nature of European Equality Regimes (bls. 59-88). Basingstoke: Palgrave Macmillan.

Bringing Human Rights Home; How State and Local Governments Can Use Human Rights to Advance Local Policy. (2012). NY: Columbia Law School, Human Rights Institute, under the auspices of the Human Rights at Home Campaign.

Council Directive 2000/43/EC implementing the principle of equal treatment between persons irrespective of racial or ethnic origin (Race Directive). Official Journal of the European Communities (L 180, 19.07.2000).

Council Directive 2000/78/EC establishing a general framework for equal treatment in employment and occupation (Framework Directive). Official Journal of the European Communities (L 303, 02.12.2000).

Drög að mannréttindastefnu Reykjavíkurborgar, 10. júní 2016. Sótt 12. október 2016 á http://reykjavik. is/sites/default/files/skjol_borgarstjornarfundur/mannrettindastefna.pdf

Drög að mannréttindastefnu Reykjavíkurborgar, dags. 7. ágúst 2015. Sótt 13. október 2015 á http:// reykjavik.is/sites/default/files/ymis_skjol/skjol_frettir/marstefnan_drog_18.8.15utsending.pdf

Frumvarp til laga um jafna meðferð á vinnumarkaði. (Lagt fyrir Alpingi á 143. löggjafarpingi 20132014.) 17. febrúar 2014. Sótt 12. október 2016 á https://www.velferdarraduneyti.is/media/frettatengt-2014/Frumvarp-til-laga-um-jafna-medferd-a-vinnumarkadi.pdf

Frumvarp til laga um jafna meðferð óháð kynpætti eða pjóðernisuppruna. (Lagt fyrir Alpingi á 143. löggjafarpingi 2013-2014.) 17. febrúar 2014. Sótt 12. október 2016 á https://www.velferdarraduneyti. is/media/frettatengt-2014/Frumvarp-til-laga-um-jafna-medferd-ohad-kynthaetti-eda-thjodernisuppruna.pdf

Guðrún Dögg Guðmundsdóttir (2011). Bann við mismunun. Tilskipanir ESB um jafnrétti án tillits til fötlunar, kynpáttar, pjódernisuppruna, kynhneigðar, aldurs, trúar og liffskeodunar. Reykjavík: Mannréttindaskrifstofa Íslands.

Hagstofa Íslands (2014). „Innflytjendur í Reykjavík eftir hverfum 1998-2014“. Sótt 14. október 2015 á http://hagstofa.is/temp/Dialog/Saveshow.asp

Helgi Guðmundsson og Guðbjörg Andrea Jónsdóttir (2015). Greining á kynbundnum launamun bjá Reykjavíkurborg 2013 og 2014. Reykjavík: Félagsvísindastofnun Háskóla Íslands. Sótt 13. október 2015 á http://reykjavik.is/sites/default/files/ymis_skjol/skjol_utgefid_efni/kynbundinn_launamunur_i_ rvk_2013-2014.pdf

Hermanin, C. og Squires J. (2012). „Institutionalizing Intersectionality in the 'Big Three': The Changing Equality Framework in France, Germany, and Britain, í A. Krizsan, H. Skjeie og J. Squires (ritstj.), Institutionalizing Intersectionality. The Changing Nature of European Equality Regimes (bls. 89-108). Basingstoke: Palgrave Macmillan.

Human Rights Cities: Motivations, Mechanisms, Implications. A Case Study of European HRCs. (2014). Ritstj. Dr. E. van den Berg. Prof. Dr. B. Oomen. Utrecht: URC University College Roosevelt. Sótt 14.10.2015 á http://kks.verdus.nl/upload/documents/HRC-Book.pdf

Ingi B. Poulsen (2014). Áfangaskýrsla umbodsmanns borgarbuia. Sótt 12. október 2015 á http://umbodsmadurborgarbua.is/sites/default/files/skyrsla_umbodsmanns_borgarbua_2014.pdf.

Innkauparáð. Fundur nr. 370. Sótt 25. nóvember 2016 á http:// reykjavik.is/fundargerd/fundur-nr-370

Innkaupastefna Reykjavíkurborgar 15. mars 2011. Sótt 13. október 2015 á http://reykjavik.is/sites/default/files/ymis_skjol/skjol_svida/Innkaupastefna_Reykjav_kurborgar_Sam_ykkt__borgarstj_ rn_15.3.2011_0.pdf

Kantola, J. (2010). Gender and the European Union. NY: Palgrave Macmillan.

Kantola, J. (2014). „The paradoxical gendered consequences of the EU policy on multiple discrimination: The Nordic case", European Integration online Papers (EIoP), Special issue 18(1), 1-19. Sótt 12.10.2016 á http:// eiop.or.at/eiop/pdf/2014-007.pdf

Kantola, J. og Nousiainen, K. (2009). „Institutionalising intersectionality in Europe: Introducing the theme", International Feminist Journal of Politics, 11(4), 459-477. 


\section{STJÓRNSÝSLA}

Krizsan, A., Skjeie H. og Squires, J., (ritstj.) (2012). Institutionalizing Intersectionality. European Comparative Analyses. Basingstoke: Palgrave MacMillan.

Lombardo, E. og Verloo, M. (2009). „Institutionalizing intersectionality in the European Union?“ International Feminist Journal of Politics 11(4), 478-495.

Mannréttindastefna Reykjavíkurborgar, sampykkt í borgarstjórn 16. maí 2006.

Mannréttindastefna Reykjavíkurborgar, sampykkt í borgarstjórn 16. maí 2006. Endurskoðun sampykkt í borgarstjórn 7. maí 2013. Sótt 14. október 2015 á http://eldri.reykjavik.is/Portaldata/1/Resources/mannr_ttindaskrifstofa/skjol/Lokastefnan_endursko_u__-_tilb._fyrir_vef.pdf

Mannréttindastefna Reykjavíkurborgar, sampykkt í borgarstjórn 18. október 2016. Sótt 25. nóvember 2016 á http://reykjavik.is/sites/default/files/mannrettindastefna_reykjavikurborgar.pdf

Mannréttindastefna Reykjavíkurborgar. (2009). Reykjavík: Reykjavíkurborg.

Mannréttindastefna Reykjavíkurborgar. (2013). Reykjavík: Reykjavíkurborg.

Menning er mannréttindi. Menningarstefna Reykjavíkurborgar 20. maí 2014. Sótt 13. október 2015 á http://reykjavik.is/frettir/menning-er-mannrettindi-ny-menningarstefna-reykjavikurborgar

Nidurstaða rannsóknarbóps um sampattingu mannéttindamála. (2005).

Oddný Mjöll Arnardóttir (2009). „Vernd gegn mismunun í íslenskum rétti: Breytinga er pörf“, Tímarit lögfradinga, 59(1), 51-83.

Oomen, B. og Baumgärtel, M. (2012). Human Rights Cities. Overview for the Sage

Handbook on Human Rights. Sótt 14. október 2015 á http://kks.verdus.nl/upload/documents/Oomen Baumgartel Human Rights Cities v2 March 13.pdf

QUING - Quality in Gender+ Equality Policies. Sótt 13. október 2015 á http://www.quing.eu/

Roosevelt, E. (1958). „In Our Hands“, ræða flutt á 10 ára afmæli Mannréttindayfirlýsingar Sameinuðu pjóðanna. Sótt 14. október 2015 á http://www.un.org/en/globalissues/briefingpapers/humanrights/quotes.shtml

Samningur Sameinuðu pjóðanna um réttindi fatlaðs fólks. Sóttur 14. október 2015 á https://www. innanrikisraduneyti.is/media/frettir-2013/CRPD-islensk-thyding---lokaskjal.pdf

Sampykkt fyrir ferlinefnd fatlaðs fólks. Sampykkt í borgarstjórn 2. september 2014. Sótt 12. október 2016 á http://reykjavik.is/sites/default/files/samthykkt_fyrir_ferlinefnd_fatlads_ folks_lokautgafa.pdf

Sampykkt fyrir Fjölmenningarráo Reykjavíkurborgar. Sampykkt í borgarstjórn 16. desember 2014. Sótt 12. október 2016 á http://reykjavik.is/sites/default/files/samthykkt_fyrir_fjolmenningarrad_0. pdf

Sampykkt fyrir ofbeldisvarnarnefnd Reykjavíkurborgar. Sampykkt í borgarstjórn 16. júní 2015. Sótt 12. október 2015 á http://reykjavik.is/sites/default/files/samthykkt_ofbeldisvarnarnefnd.pdf

Sampykkt fyrir Öldungaráð Reykjavíkurborgar. Sampykkt í borgarstjórn 16. desember 2014. Sótt 12. október 2016 á http://reykjavik.is/sites/default/files/samthykkt_fyrir_oldungarad.pdf

Skýrsla starfshóps um tilskipanir Evrópusambandsins um bann vio mismunun. (2008). Reykjavík: Félags- og tryggingamálaráðuneyti.

Starfsmannastefna Reykjavíkurborgar 19. desember 2001. Sótt 14. október 2015 á http://reykjavik.is/ sites/default/files/ymis_skjol/skjol_utgefid_efni/starfsmannastefna_12_2001.pdf

Stefna Háskóla Íslands gegn mismunun (2005). Sampykkt á Háskólafundi 18. febrúar 2005. Reykjavík: Jafnréttisnefnd Háskóla Íslands.

Stjórnarskrá Lýðveldisins Íslands nr. 33/1944, Stjórnskipunarlög nr. 97/1995, 65. gr.

Thorvaldsdóttir, Th. og Einarsdóttir, Th. (2011). „Equality discourses at crossroads: Gender equality versus diversity”, í E. H. Oleksy, J. Hearn \& D. Golanska (ritsti.), The limits of gendered citizenship: Contexts and complexities (100-122). NY: Routledge.

Upplýsingastefna Reykjavíkurborgar 2015-2020. Sótt 14. Októrber 2016 á http://reykjavik.is/sites/ default/files/upplysingastefna_-_samthykkt_0.pdf

Verloo, M. (2006). „Multiple inequalities, intersectionality and the European Union“, European Journal of Women's Studies, 13(3), 211-228. 
Verloo, M. (2011). Gender equality policies as interventions in a changing world. Fyrirlestur fluttur á ráðstefnunni The 2nd Gender and Politics ECPR Conference, Budapest.

Woodward, A. E. (2004). Diversity? The Europeanization of difference and the influence of the United States on conceptualizations of equality policy. Fyrirlestur fluttur á ráðstefnunni The inclusion and exclusion in contemporary European societies.

Yuval-Davis, N. (2006). „Intersectionality and feminist politics“, European Journal of Women's Studies, 13(3), 193-209.

एjóð til pings. Frumvarp til stjórnskipunarlaga. Stjórnlagaráð 2011. Sótt 12. októrber 2016 á http:// www.stjornlagarad.is/other_files//stjornlagarad/Frumvarp-til-stjornarskipunarlaga.pdf

Dorgerður H. Porvaldsdóttir (2012). From Gender Only to Equality for All: A Critical Examination of the Expansion of Equality Work in Iceland. Doktorsritgerð frá Háskóla Íslands.

Dorgerður H. Dorvaldsdóttir (2014). „Jafnrétti fyrir alla: Eitt markmið, ólíkar leiðir“ í Annadís Gréta Rúdólfsdóttir, Guðni Elísson, Ingólfur Ásgeir Jóhannesson og Irma Erlingsdóttir (ritsti). Fléttur III - jafnrétti, menning, samfélag (285-309). Reykjavík: Rannsóknarstofnun í jafnréttisfræðum, Háskólaútgáfan. 
